\title{
THE DIFFICULT QUEST FOR A UNIFORM MARITIME LAW: FAILURE OF THE BRUSSELS CONVENTIONS TO ACHIEVE INTERNATIONAL AGREEMENT ON COLLISION LIABILITY, LIENS, AND MORTGAGES
}

WhENEVER a vessel engaged in international trade is the subject of a legal claim or controversy, it is possible that the law of any one of a number of nations may apply, or even that of several simultaneously. ${ }^{1}$ But if the admiralty courts of each nation enforce rules and remedies which vary greatly from those of other maritime states, confusion and unpredictability are sure to follow. For this reason, commentators have suggested that a uniform law for the high seas is a logical complement to the technology which has made international commerce possible. ${ }^{2}$

At the end of the nineteenth century, international accord on matters of maritime law was virtually non-existent. ${ }^{3}$ Since that time, various efforts have been made to improve the situation. ${ }^{4}$ The most sustained and extensive drive has been that of the Comité Maritime International, an organization comprised of representatives of business and legal interests from the leading marine nations. " The Comite had its first meeting in 1897, and continues today as an active organization. Early in its history, it became apparent that the most practical way of achieving uniformity was by a series of trenties. ${ }^{0}$

The Comité has drafted nine agreements, known as the Brussels Conventions. They deal with such problems as salvage, collision liability, limitation of shipowners' liability, maritime liens and mortgages, bills of lading, and the arrest

1. For illustrations, see text at notes 14 and 81 infra.

2. Secretary of State Cordell Hull wrote of the Brussels Collisions Convention:

"The convention is one result of a general movement on the part of comnercial nations of the world to attain a certain measure of uniformity in their laws to aid and promote the international exchange of goods. I feel that business will be aided by harmonizing the laws of the several countries so that persons who carry on trade can know with more certainty their exact legal rights and obligations."

Letter to Senator Key Pittman, dated June 13, 1939, printed in 1939 Am. Mar. Cas. 1068.

See also Nielsen, The Lack of Uniformity in the Law and Practice of Statcs with Regard to Merchant Vessels, 13 An. J. INr. L. 1 (1919); Franck, A Ncw Laze for thr Seas, 42 L.Q. Rev. 25 (1926).

3. Franck, supra note 2.

4. A comprehensive study of efforts to achieve international accord by treaty may be found in 4 BENEDict, AdMiralty $\$ 620$ (6th ed. 1940).

5. An account of the inception and early growth of the Comite is given in Franck. supra note 2.

6. See Franck, supra note 2 , at 27.

The propriety of changing established domestic law by means of international treaties was soon challenged. Id. at 28 . This argument was voiced against the Collisions Convention in the United States. See text at note 33 infra. 
of ships." The vision of the Comite's founders was a "new law of the high seas," extending to all incidents of international ocean commerce. But this dream is today in large part unfulfilled. From the beginning, the principle of uniformity has come into conflict with various private interests which have felt that the added convenience of international accord and predictability would not compensate for the economic disadvantages of alteration of national law.

Of the nine conventions, only two have been ratified by the United States. ${ }^{8}$ And Great Britain, the other leading maritime nation, although more receptive to the work of the Comité, has also failed to ratify several key conventions. ${ }^{0}$ This comment will examine the failure to win American approval of the Brussels Conventions dealing with collision liability and with maritime liens and mortgages. It will attempt to further understanding of the actions of the commercial interests affected and to suggest steps that might profitably te taken among maritime nations at this time.

\section{Collision Liability}

Civil liability following a collision between ressels was one of the initial subjects dealt with by the Comite Maritime International. The Brussels Conventions to create uniformity in the laws of salvage and collision liability were the first ones drafted, being completed in 1910. The Salvage Convention won approval in the United States without undue trouble largely because it enacted existing American principles, ${ }^{10}$ but the Collisions Convention has been the target of bitter opposition. Although the American delegates to the 1909 conference subscribed to the draft, subject to certain reservations, ${ }^{11}$ it has

7. The other conventions involve the immunity of state owned ships, and civil and penal jurisdiction in collision cases. All nine conventions are discussed in 4 BestepltT, AdMIRAlty 258-69, 273-77 (6th ed. 1940).

8. These are the Salvage Convention of 1910 and the Ocean Bills of Lading Convention of 1924 (usually referred to in the United States as the Carriage of Goods by Sea Act, 49 Stat. 1207 (1936), 46 U.S.C. $\$$ 1300-15 (1952)). They are printed in 6 Benedit, AdMIRALTY 200, 154 (6th ed. 1940).

9. Great Britain has not ratified the conventions regarding limitation of liability, and maritime liens and mortgages.

10. Ratification occurred on January 25, 1913. 37 Srat. 1658 (1913). "This convention, except in a few paragraphs, states the law of salvage as it now exists in the United States." Axserican Delegates to the Third International Conference ui: Maritiare LAW, REPORT 14 (1909), recommending ratification.

11. Ibid. The convention is reprinted in full in 6 Benedict, Adssiralts 4 (6th ed. 1940). See note 15 infra for its key provisions.

Under instructions from the State Department, the United States delegates signed the convention subject to four reservations. These provided that: (1) The conventiun's proportional fault rule would not affect the operation of the Harter Act; (2) The convention would not create a right of action for wrongful death until such provisions were supported by appropriate acts of Congress; (3) The provisions of Article 6 of the convention would not in any way affect legal presumptions created by the laws of the United States; (4) The provisions of the convention would be applicable only in Ameriean federal courts of admiralty, and not in the state courts. For the subsequent history of these reservations, see text at notes 51 and 66 infra. 
never been ratified by this country. A favorable report by a Senate subconmittee in 1939 represented the convention's high-water mark. ${ }^{12}$ America's failure to ratify has left its law of collision liability unique among the maritime nations of the Western world. ${ }^{13}$

In pre-convention days, the legal consequences of a collision between vessels of diverse flags often varied from one forum to another. A late nineteenth century collision which gave rise to litigation in three countries well illustrates the situation. ${ }^{14}$ Both ships were at fault, in differing degrees. Both suffered hull damages, and there were cargo losses on each; in addition, a death claim was brought by the relatives of a Dutch seaman. Suits resulted in England, Belgium, and Holland; and, although the identical fact situation was involved, the three countries determined liability in three different ways. The English court divided the material damages equally between the vessels. In Belgium, material damages were awarded on a proportional fault basis. And in the Dutch court, the death claimants were denied all recovery on a strict common-law theory of contributory negligence.

The Collisions Convention of 1910 put forward one central concept. Where a collision occurs between sea-going vessels or between sea-going vessels and vessels of inland navigation, and if two or more vessels are at fault, the liability of each for property damage shall be in proportion to the degree of fault, without joint and several liability to third parties. ${ }^{15}$ Thus, if a vessel is one-third at fault, it will be liable for only one-third of the damage to the other vessel or its cargo, or to the property of the crews, passengers, or other persons on board either

12. S. Rep. Exec. No. 4, 76th Cong., 1st Sess. (1939). The report is reprinted in 1939 Am. Mar. Cas. 1051.

13. The United States is the only major maritime nation which has not ratified the Collisions Convention of 1910. For a list of adhering countries, see 6 Benedict, AdMikstity 4 (6th ed. 1940).

14. The litigation is described by Franck, A New Law for the Seas, 42 L.Q. Rev. 25 (1926). It was this case which led M. Franck to examine other aspects of international maritime law, and to become active in the founding of the Comite Maritime International, of which he became president.

15. Following are vital provisions of the convention:

"Article 1. Where a collision occurs between seagoing vessels or between se'sgoing vessels and vessels of inland navigation the compensation due for damages caused to the vessels, or to any things or persons on board thereof, shall be settled in accordance with the following provisions, in whatever waters the collision takes place.

"Article 2. If the collision is accidental, if it is caused by force majcurc, or if the causes of the collision are in doubt, the damages shall be borne by those who have suffered them.

"This provision shall be applicable nothwithstanding the fact that the vesscls, or any one of them, may have been at anchor (or otherwise made fast) at the time of the casualty.

"Article 3. If the collision is calused by the fault of one of the vessels, liability to make good the damages shall attach to the one which has committed the fault.

"Article 4. If two or more vessels are in fault the liability of each vesuel shall be in proportion to the degree of the faults respectively committed. Provided that if, 
vessel. No carrier can be held directly liable to its own cargo for damage caused by negligence, under the universally accepted Brussels Convention on Ocean Bills of Lading, ${ }^{16}$ which was based on the principles of the American Harter Act. ${ }^{17}$

The convention's system of proportional fault excited the opposition of American cargo interests and has prevented its ratification by the United States to this day. Where vessels collide and cargo is damaged, American law holds that cargo is entitled to one hundred per cent recovery if both vessels are in any degree at fault. Under the provisions of the Harter Act, cargo may not recover from its own carrier for damages resulting from the negligence of captain and crew. ${ }^{18}$ But American case law permits a one hundred per cent recovery from the non-carrier, even where that vessel's fault was only minur. ${ }^{10}$

having regard to the circumstances, it is not possible to establish the degrec ui the respective faults, or if it appears that the faults are equal, the liability shall bu apportioned equally.

"The damages caused either to the vessels, or to their cargoes, or to the efficts or other property of the crews, passengers, or other persons on board, shall be borne by the vessels in fault in the above proportion without joint and several liability toward third parties.

"In respect of damages caused by death or personal injury, the vessels in fault shall be jointly as well as severally liable to third parties, without prejudice to the right of recourse of the vessel which has paid a larger part than that which in accordance with the first paragraph of this article she ought ultimately to bear.

"It is left to the law of each country to determine, as regards such recourse, the scope and effect of any legal or contractual provisions which limit the liability of the owners of a vessel toward persons on board."

For the full 18 articles, see 6 Benedict, Adarirality 4 (6th ed. 1940).

16. The Convention is reprinted in 6 id. 154.

17. 27 StAT. 445 (1893), 46 U.S.C. $\$ \$ 190-95$ (1952). See note 18 infro.

18. 27 Stat. 445 (1893), 46 U.S.C. $\$$ 190-95 (1952). The Harter Act was altured in some respects by the Carriage of Goods by Sea Act, 49 STri. 1207 (1936), 46 U.S.C. $\$ \S 1300-15$ (1952), the American implementation of the Brussels Convention on Oetan Bills of Lading (the "Hague Rules"), which the United States ratified on April 16, 1936. The field of marine bills of lading is one where virtual international uniformity has been achieved. See Robinson, Amartralty 495-503 (1939).

Under both American statutes, the immunity of a shipowner from liability to cargu for the negligence of his servants is conditioned upon the shipowner exercising due diligence in furnishing a seaworthy vessel. The Carriage of Goods by Sea Act is more advantageous to the shipowner, however, since it requires cargo to prove that tive inilure to exercise due diligence was in some way a proximate or contributing cause of the loss. Under the Harter Act, cargo need only prove a lack of due diligenee in furnishing a ship seaworthy in all respects, regardless of causal connection. Note, $27 \mathrm{VA}$. L. Rex. 1079 (1941) ; 3 Benedict, Adariralty $\$ 95$ (6th ed. 1940). See alsu The Isis, 290 [־.S. 333 (1933).

19. This principle was established in The Alabama and The Gannevels, 92 C.S. 65 (1875); and The Atlas, 93 U.S. 302 (1870). In permitting full rccovery against uns vessel where two were to blame, the Supreme Court refused to iullow the English case law on cargo's remedies. Prior to ratification of the Collisions Convention, England limited cargo to a 50\% recovery against the non-carrier, even though the bill of lading invariably prevented cargo from recovering anything frum the carrying ship. The Milan, 1 Lush. 38S, 167 Eng. Rep. 167 (1861). The English court in The Milan 
Against this background, the disadvantages to cargo of the convention rule of proportional fault become clear. The Harter Act would continue to bar an action by cargo against its own vessel; and the non-carrier could be recovered from only to the extent of its proportional blame. Assuming a both-to-blame collision, cargo would always stand to lose something. ${ }^{20}$

American shipowners, on the other hand, greeted the convention principles with enthusiasm. Their immunity under the Harter Act from liability to their own cargo had become, in the event of a both-to-blame collision, jeopardized. Under the famous decision of the Supreme Court in The Chattahoochic, after the non-carrying vessel has been assessed for one hundred per cent recovery by the other ship's cargo, it may then require a contribution of half this amount from the carrying vessel..$^{22}$ The anomalous result of The Chattahoochie was to make a carrier indirectly liable to its cargo for half the damage when only partially at fault, although totally absolved when entirely at fault. ${ }^{23}$ Shipowners sought to escape the effects of The Chattahoochic by writing into bills

believed that where cargo on vessel $A$ sues vessel $B$ for damages arising out of a both-toblame collision, vessel $B$ should not be required to pay more than half the cargo's damages. To hold vessel $B$ liable in full when it was only partially at fault, it reasoned, would be unjust. The United States Supreme Court, in The Atlas, had no such diffictilty in decreeing a $100 \%$ recovery for cargo against vessel $B$. It stressed that cargo was chtircly innocent, and deserved full recompense, even though this caused certain hardships to vessel $B$.

The English recovery rule of The Milan has, of course, been altered by the provisions of the Maritime Conventions Act of 1911, by which England put into effect the Brussels Collisions Convention. Marsden, Colnisions AT SEA 158 (10th ed. 1953).

20. For full discussion of the economic consequences of the Collisions Convention if ratified by the United States, see Huger, The Proportional Damage Rule in Collisions at Sea, 13 CORNELI. L.Q. 531 (1926).

21. 173 U.S. 540 (1899).

22. For a good discussion of the case, see Robinson, Admrralty 867-70 (1939).

American law decrees an equal division of all damages between the two vesscls when both ships are at fault, even where the degrees of fault differ. Rosinson, Admiralty 853 (1939). Thus, where vessel $A$ is damaged to the extent of $\$ 10,000$, vessel $B, \$ 10,000$, and $A$ 's cargo, $\$ 10,000, B$ is entitled to add cargo's recovery from her to her own damages. This gives a total of $\$ 30,000$, and renders $A$ liable for a total of $\$ 15,000$. $A$ will bear her own loss of $\$ 10,000$, and pay $B \$ 5,000$, which sum is, in effect, half of the loss suffered by $A$ 's own cargo.

Ratification of the Collisions Convention would, of course, alter the American rule of equal division of damages to one of proportional liability. See note 15 supra and accompanying text.

23. The Chattahoochie certainly seems to negative the effect of the Harter Act in at both-to-blame collision. See Robmson, Admiralty 864 (1939). But differing opinions have been expressed as to whether Chattahoochie's result is genuinely anomalous. It has been argued that the Harter Act was intended to affect only the relations between the carrier and its cargo, and therefore has no application when the non-carrier settles with the carrier. See Green, The Harter Act, 16 HArv. L. Rev. 157 (1903).

On the other hand, M. Franck, of the Comité, declared: "Here is the point. Both ships are to blame. My cargo is in ship A. I cannot recover from ship A uncler the negligence clause, but $I$ am paid full damages by ship $B$, and ship $B$ collects from ship A her share in my damage. Do you call that law? If you say the Harter Act is 
of lading the "both-to-blame" clause, whereby cargo was required to indemnify" the carrier for its cargo damage contribution to the non-carrier. ${ }^{24}$ But the legality of the both-to-blame clause came under early attack by cargo interests, who were confident that the Supreme Court would invalidate it. ${ }^{25}$ If the convention were ratified, the carrier's freedom from indirect liability to its cargo in a both-to-blame collision would be assured as a matter of national policy without risking the hazards of litigation. ${ }^{20}$

wrong, if you say the universal convention of 1923 is wrong, all right, get it suppressed. But if it is not suppressed, you can't consider that an interpretation of law is sound which permits you to get around the agreed principle. You may defend it, if you like, all you like-but it is not justice." Address by Louis Franck, U.S. Maritime Law Ass in meeting. reprinted in U.S. Maritiare Law Ass's, Proceenrags (Duc. No. 139, 1927).

In its most recent pertinent opinion, the Supreme Court did not consider the results of Chattahoochie as intolerably anomalous. "It is said to be 'anomalous" to hold a carrier not liable at all if it alone is guilty of negligent navigation but at the same time to hold it indirectly liable for one-half the cargo damages if another ship is jointly negligent with it. Assuming for the moment that all rules of law must be symmetrical, we think it would be 'anomalous' to hold that a cargo owner, who has an unquestioned right under the law to recover full damages from a noncarrying vessel, can be compelled to give up a portion of that recovery because of a stipulation exacted in a bill of lading." United States v. Atlantic MIut. Ins. Co. (The Esso Eelgium), 343 U.S. 236, 238 (1952). This was the decision which invalidated the "both-to-blame" clause in bills of lading. Sce test at note 74 infra.

24. A typical both-to-blame clause is printed in Robmson, Ansmanty 872 n.211 (1939), and reads as follows:

If the ship comes into collision with another ship as a result of the negligence ui the other ship and any act, neglect or default of the master, mariner, pilot or the servants of the Carrier in the navigation or in the management of the ship, tite owners of the goods carried hereunder will indemnify the Carrier against all luss or liability to the other or non-carrying ship or her ouners insofar as such loss or liability represents loss of, or damage to, or any claim whatsoever of the owners of said goods, paid or payable by the other or non-carrying ship or her ouners to the owners of said goods and set off, recouped or recovered by the uthor wr nuncarrying ship or her owners as part of their claim against the carrying ship or Carricr.

See also Knauth, OcEax Binls of Lading 101 (4th ed. 1953). The effect of the clause was to limit cargo to $50 \%$ recovery where both vessels were to blame.

25. Before a Senate subcommittee conducting hearings on the Collisions Conventiun, D. Roger Englar, the principal spokesman for American cargo interests, stated that he had counseled cargo underwriters against increasing premiums when the buth-to-blame clause was included in the bill of lading. His position was that the clause was invalid, and that charging an extra premium in response to it would imply that the clause had been accepted. See Hearings Before Senate Subcommittee on Forcign Relations on Rules to Govern the Liability of Vessels When Collisions Octur Betwen Them, 75th Cong., 3d Sess. 374 (1938) (hereinafter referred to as Hearings).

At the time of the hearings, a district court had held the buth-tu-blam clause valits. The San Vicente, 1+ F. Supp. S94 (S.D.N.Y. 1936). But cargo's josition sas ultinat ly justified when the Supreme Court invalidated the clause in Unitud States v. Atlantic Mut. Ins. Co. (The Esso Belgium), 343 U.S. 236 (1952). See text at $n$ ste 74 iafro.

26. The advantages of the convention in this respect were stated ly Charles $S$. Haight, chief advocate of ratification:

"Now, if the convention gives the same results as the clause, but the clause has gut to be litigated, clear through the Supreme Court, why do you nut take the sulution 
Controversy came to a head when in 1937, twenty-seven years after the American delegates had signed the original draft, the executive branch of the government recommended the convention to the Senate. ${ }^{27}$ Five days of energetic debate took place before Senator Schwellenbach's Subcommittee on Foreign Relations. ${ }^{28}$

Spokesmen for American cargo interests first advanced the protest, familiar in present times, that the convention was "un-American." It was suggested that the convention was the product of foreign, primarily shipowning nations, and that the American delegates had merely been invited to accept or reject an accomplished fact, with scant heed paid to their views. ${ }^{20}$ Impetus for the Convention, the argument ran, came from European shipowners whose real concern was economic gain and not uniformity of law; therefore, domestic interests should not be sacrificed to further this end. ${ }^{30}$

More persuasive was cargo's contention that a fundamental change in its right to recovery should be effected, if at all, as part of an overall congressional

which avoids all this litigation by ratifying the convention, the solution which will accomplish the same results as litigation?"

Hearings, p. 272.

27. A number of causes combined to delay executive action on the convention. The controversy stirred by cargo underwriters postponed any definite American action until the conclusion of World War I. In 1922 the then Secretary of Commerce, Herbert Hoover, advised that the Collisions Convention be held in abeyance until other Brussels Conventions then under discussion were also ready for submission. The result was to bury the Collisions Convention for another fifteen years. Finally, in 1937, the convention was sent to the Senate with the approval of the President, the State Department, and the Secretary of Commerce. These historical details are taken from the testimony of Francis B. Sayre, Assistant Secretary of State, before the Senate subcommittec. Sce Hearings, p. 35-36.

28. The report of the subcommittee was signed by Senators Schwellenbach, Pepper, and White. However, except for a brief appearance by Senator Pepper, the arguments weré conducted before Senator Schwellenbach alone.

29. This suggestion was made to Charles C. Burlingham, one of the United States subscribers to the convention in 1910. Mr. Burlingham refuted the suggestion, and Senator Schwellenbach pointed out that the draft the United States delegation signcd in Brussels in 1910 had been fully studied for a year in this country by the State Department. See Hearings, pp. 76, 77.

30. Mr. Englar stated in his testimony:

"I think we should clearly have in mind this: that every dollar you take away from the American shipping public by this shift goes as to more than half of it to foreigners .... Anyone who will take the trouble to follow the various international conferences will have no delusions at all as to the motivating force bihind the delegates from the different countries. It may be pure coincidence, but you will find that their views always coincide with the general interest of the country that they represent economically."

Hearings, p. 375.

In a statement included in the record, the National Industrial Traffic Leigrte, a national organization of shippers and receivers of commorlitics, p sed this rhetorical question:

"Even if such a movement as this were started by American-ship owners (which it was not), it might be considered seriously, but not favorably, by American ex- 
revision of American maritime law. Cargo viewed full recovery as "a very ancient, universal right." 31 Its representatives argued that although Chatlahoochie may have led to anomalous results, this right of cargo was in no way dependent upon that case; nor had the Harter Act affected that right.32 Ratification of the convention principles, they maintained, would thus deprive cargo of a long-vested interest. Therefore, the only fair way of altering the maritime law was by means of domestic legislation taking into account more than one particular problem. ${ }^{33}$ This insistence by cargo upon change by the whole Congress rather than by the Senate alone, however reasonable in itself, had also decided tactical advantages. The principal spokesman on behalf of the Collisions Convention had admitted that it would be far more difficult to obtain approval of the Brussels principles in the form of a House bill than to secure Senate ratification of the treaty. ${ }^{34}$ This admission was seized upon as

porters and importers; who would give up substantial rights which they now have, and why do this to please a group of foreign underwriters?"

Hcarings, p. 455 .

On the other hand, a memorandum prepared by the Unitcd States Maritime Cummission commented:

"Considering the matter as a whole, it would arncar that the "foreign influentee" argument is not entitled to much weight. The division of interest ratier is betucen P. \& I. underwriters (foreign and American) as opposed to cargo underwriters (foreign and American)."

Hearings p. 44.

31. Hearings, p. 123.

32. The right of $100 \%$ recovery was viewed as the right to recorer in iull against one of two joint tort feasors. Hcarings, p. 123.

While cargo's spokesman insisted that the Harter Act shutd lawe no effect upon cargo's right to be made whole, he was willing to concede that the Act could be cunstrued as putting an end to the non-carrier's right of contribution from the carrying vessel for cargo liability.

"Mr. Englar: Now, it might be very logical, in view of the Harter Act, fur the Supreme Court to say that the non-carrying vessel did not have any right of contribution but I do not see that it would have boen at all logical to say that cargo could not recover against the perfect stranger."

Hearings, p. 125. This would have required the non-carrier to pay cargo in full, no matter what her degree of fault.

33. Hearings, pp. $369,387-\& s$.

Ira A. Campbell, who represented certain American shipowners, joincd cargo in arguing that domestic legislation should precede ratification of the convention, bacause of the differences the treaty would bring about in American law. Hcarings, p. 192. However, he emphasized that the "primary purpose" of the convention-immunity of the carrier from liability to its cargo-had already been achieved by the insertion of the both-to-blame clause in bills of lading. Hearings, p. 177. Since that tine, husever, the both-to-blame clause has been heid invalid by the Supreme Court. Cnited states v. Atlantic Miut. Ins. Co. (The Esso Belgiurn), 343 U.S. 236 (1951). See text at note 74 infra.

34. "Mr. Haight: I know that the argument will be made that we shuuld drop this convention and go ahead and pass a law. Mír. Englar, I am sure, will want thast course followed. He is opposed to the rules in the cunventiun and il is anste olvious that he will have a much better chance of defcating the present efiort to get ani- 
evidence of something like bad faith on the part of the convention's advocates, ${ }^{\text {st }}$ and undoubtedly influenced cargo's enthusiasm for domestic legislation as the proper procedure.

In assailing the alteration of "a basic right" through ratification of a treaty which would leave other aspects of the maritime law unchanged, cargo's notion was that of a quid pro quo. If it was to lose something, it should get something in return. Casting about for a suitable quid, cargo's counsel suggested a possible economic gain for his interests through alteration of the law on limitation of a shipowner's liability. ${ }^{36}$

All maritime nations follow some scheme of limitation of the shipowner's liability. ${ }^{37}$ In the United States, property claims against a vessel are limited to the value of the ship after the disaster. ${ }^{38}$ If the vessel is totally lost, the owner is liable only to the extent of his interest in the "freight then pending": passenger fares as well as cargo income. ${ }^{39}$ English law decrees a fund of $E 8$ per ton for property damage, but limits liability to that amount. ${ }^{40}$ The Brussels Convention on limitation of liability, which neither the United States nor Great Britain has ratified, adopts a compromise between the British system of fund forfeiture and the American system of abandonment and surrender of the ship's value. ${ }^{41}$ For property damage, recovery cannot exceed the $E S$ per ton fund figure; but if the value of the vessel after the disaster is less than £8 per ton, the owner is liable only in that lesser amount. It is provided, however, that the "freight then pending" is always deemed to be ten per cent of the value of the vessel at the start of the voyage so that property damage claimants will have a substantial minimum fund upon which to rely. ${ }^{42}$

Cargo declared during the hearings that if it was time to decrease its recovery in both-to-blame collisions, perhaps it was also time to establish a fund out of which cargo claims could be satisfied even if the vessel was a total loss. Cargo interests, it was suggested, might look with more favor on the

formity if he can oppose the bill in the House of Representatives, beforc the convention is ratified, than he will after the convention has been ratificd. After we have ratified the convention everybody will say that this is the right rule and, of course, we will extend it to everybody and be through with it."

Hearings, p. 117 (emphasis added).

35. Hearings, p. 376.

36. Hearings, p. 369.

37. Robinson, Admiralty 877 (1939).

38. 16 Stat. 458 (1871), 46 U.S.C. $\$ \$ 181-89$ (1952). For a review of the development of limitation legislation in the United States, see Robinson, Admiralty 879-80 (1939).

The shipowner's right to limit his liability is not absolute; rather, it is conditioned upon the loss being occasioned without his "privity or knowledge." For a discussion of this requirement, see $i d$. at 941-50.

39. Id. at 930-34. A different limitation is provided for losses arising out of death or personal injury. Such claimants are guaranteed recovery from a fund equal to $\$ 60$ per ton by the 1935 and 1936 amendments to the act. Id. at 938 .

40. 3 Benedict, Admiralty 638 (6th ed. 1940).

41. The full text of the convention is printed in $6 \mathrm{id} .87$; and $1923 \mathrm{Am}$. Niar. Cas. 84\%.

42. 4 Benedict, AdMiralty 274 (6th ed. 1940). 
Collisions Convention if a sixty dollar per ton fund, presently available under American law only for death and injury claims, ${ }^{43}$ were also made accessible to cargo claims. ${ }^{44}$ This would enhance cargo's recovery in cases of total loss, and would compensate it in some measure for the economic disadvantages of the Collisions Convention.

Interjection of the limitations problem into the controversy over collision liabilities indicates the extent to which the unique features of admiralty law: are interrelated. It is difficult to alter one without becoming seriously involved in problems as to others. ${ }^{45}$ For this very reason, it was the original goal of the Comite to provide for all aspects of the martime law by a series of Brussels Conventions. ${ }^{46}$ Because the United States, in addition to Great Britain, had failed to ratify the convention on limitation of liability, cargo was able to argue that ratification of the Collisions Convention would not produce complete uniformity in the matter of collision liability. Even though agreement as to liability would result, differences as to the limitation of that liability would remain. ${ }^{47}$

The opponents of the Collisions Convention foresaw other undesirable results stemming from ratification. They predicted that efforts to apportion fault would be difficult to administer and would add to litigation, ${ }^{\mathbf{3}}$ and that insurance rates

43. See note 39 supra.

44. Mr. Englar's suggested statutory amendment was as follow's:

"In the case of any seagoing vessel the amount of the owner's liability as limited under subsection (a) shall in no event be less than $\$ 60.00$ per ton of such ressel's tonnage to be available in the first instance for the payment of lusses in resfrect of loss of life or bodily injury and, after payment of such losses in full, for the payment of any other losses for which the owner may be liable."

He prefaced the reading of the suggested amendment into the recurd with the worls: "I am not sure that if he [MIr. Haight] will consent to this, I won't consent to his confounded convention, bad as it is. But I want to put this in to show that I am not just down here because maybe somebody is taking a dollar away from me. IVe will be fair. I am not so sure but that XIr. Campbell and I can get tugether and work something out. But I will say this: He will have to give us something. I am ready to give up, but he has got to give something up too."

Hearings, pp. 368, 369.

45. American shipowners have recognized this as clearly as have cargo interests. They have been wary of seeking to introduce the Collisions Convention principles into domestic law, fearing that cargo would retaliate by attacking the limitation of liability statutes. See Hearings, p. 157.

46. See Franck, $A$ New Law for the Seas, 42 L.Q. Rev. 25 (1926).

47. For example, where vessel $A$ is one-third at fault, vessel $B$ is two-thirds at iault, and cargo on $A$ is damaged, ratification of the Collisions Convention would mean that in all countries cargo could fecover no more than two-thirds of its damages against vessel $b_{\text {. }}$ But if vessel $B$ is a total loss, the recuveries possible under American and English law: would still differ. In America, cargo would recover no more thas any perding freight. See text at notes 38-39 supra. In England, cargo would have the benefit of an fS per ton fund. See text at note 40 supra.

Cargo made this point at the hearings in order to show that the uniformity stres:ed by the convention's advocates as its chief merit was in part illusory. Hcarings, p. 152.

48. Hearings, pp. 182, 240. 
on cargo shipments would rise. ${ }^{49}$ Furthermore, much concern was voiced over article six of the convention, which provides: "There shall be no legal presumption of fault in regard to liability for collision." When the United States signed the convention in 1910, it reserved the right not to be bound by this provision. ${ }^{50}$ But by the time the draft reached the Senate subcommittee, this reservation had been dropped. ${ }^{51}$ Article six, its critics claimed, would destroy a number of presumptions established by American case law, with resulting confusion in our admiralty practice. ${ }^{52}$

Not unnaturally, the proponents of the Collisions Convention preferred to stress the need for international uniformity rather than ratification's econonic advantages to shipowners. They emphasized that the United States was the only major maritime power that did not abide by the convention rules. Therefore, it was high time to ratify a convention which this country had signed in 1910 in order to put an end to uncertainty and forum-shopping. ${ }^{53}$ It was urged that only by ratification of the convention could genuine uniformity be achieved; subsequent domestic legislation would be a desirable supplement, extending the convention's principles to collisions involving exclusively American vessels and cargoes. ${ }^{54}$

Furthermore, the convention's advocates claimed that ratification, rather than tampering with "ancient rights," would instead give full effect to the policy underlying the Harter Act." They agreed that cargo's right to re-

49. Hearings, p. 372.

50. See note 11 supra.

51. The executive branch of the Government felt that the "apparent unimportance" of American statutory and judicial presumptions warranted dropping the reservation. Hearings, p. 35.

52. The most discussed of these presumptions was the rule of The Pennsylvauia, 86 U.S. (19 Wall.) 125 (1874). The Supreme Court held that in a suit arising out of a collision, if the plaintiff proves the defendant violated a safety statute which might be causally connected with the collision, the court will presume that such violation was a cause of the collision unless the defendant proves, not only that it was not but that it could not have been a cause.

The assumption during the hearings was that the Collisions Convention would, indecd, do away with such judicial presumptions. Government sponsors of the convention believed they were not particularly important. See note 51 supra. Opponents of ratification felt abolition of judicial presumptions would upset accepted practice, and cause officers and crewmen to become careless in ship handling. Hearings, p. 178.

However, Benedict takes the position that Article 6 of the convention applics only to statutory presumptions, and not to those created independently by case law and that the French text of the convention was inaccurately translated. In the ficld of collision law, the only statutory presumption is that of the Stand-By Act, 26 STAT. 425 (1890), 33 U.S.C. $\$ 367$ (1952). It provides that a shipmaster who fails to stand by after a collision is presumed at fault. See 4 BENEdict, AdMIRAlty 263-67 (6th ed. 1940).

53. Hearings, pp. 37, 115-16. These pages contain representative remarks.

54. Domestic legislation was deemed necessary in order to extend the rules of the convention "to every case where all of the interests are American, and where, as an obvious matter of propriety, the convention does not cover it." Hearings, pp. 116, 117, 120.

55. Hearings, pp. 113-14. 
covery did not stem from Chattahoochie $; 0$ but they argued that the Harter Act was intended to undermine that right by immunizing a carrier from liability to its own cargo. Therefore, if cargo could not recover from its carrier in a collision where the carrier was solely at fault, a fortiori it should not recover where the carrier is only partially so. ${ }^{57}$ And the convention rules only practice simple justice in restricting recovery against the non-carricr to its share of the blame.

As for the practical difficulties which cargo alleged were inherent in the Collisions Convention, its proponents pointed to its smooth functioning in the ratifying nations, notably England, over the previous twenty-five years. ${ }^{2: 2}$ Insurance rates had not gone up; 59 nor had the proportional fault system proved unmanageable. With respect to the latter point, a questionnaire was placed into the record demonstrating that 26 of 28 federal district court judges polled were in favor of altering the American rule of splitting the damages in both-to-blame collision cases to one of proportional fault; ${ }^{60}$ moreover, it was argued that American admiralty lawyers assessed proportional fault all the time in arriving at settlements out of court. ${ }^{61}$

Considering the desirability of uniformity to be decisive, Senator Schwellenbach's subcommittee recommended American adherence to the Collisions Convention. ${ }^{62}$ Cargo's objection-that, even if any changes were necessary, domestic legislation should be adopted in lieu of adherence to the convention-was dealt with in short order. The committee believed that adoption of the convention was the more orderly and customary procedure. "It is a procedural

56. See text at note 32 supra. Cargo's right to $100 \%$ recovery from the non-carricr stems from Supreme Court decisions in The Alabama and The Gamecocl, and The Allos, which disapproved the English rule of The Milan. See note 19 supra. These decisions preceded Chattahoochie by twenty-four years, and form the real basis for cargo"s "very ancient, universal right." See text at note 31 supra.

57. The contrasting ways of viewing the effect of the convention on American law: are well illustrated by this exchange:

"IIr. Haight: Well, now, isn't it a matter of fact that when it is the rolicy of this country, as of all others, that a shipowner shall pay nothing when the ship is solely at fault for a collision, doesn't it seem to you anomalous that the owner must pay half of the damage to his own cargo when his ship is half at iault?

"Mr. Englar: It seems to me that a more accurate way to state the effect of this convention would be to say that a right which the cargo has against a third party is to be taken away from it because its own ship is guilty of a jault. That doesn't seem to me to have any logic at all."

Hearings, p. 407.

58. Mr. Sayre, Assistant Secretary of State, commented that "thirty-one countrics have now put it into successful operation." Hearings, p. 33. Mrr. Englar, opposing the convention, suggested that since the bulk of collision litigation was conducted in England or the United States, this figure was not as impressive as it scemcd. Hcarings, p. I8.

59. Hearings, pp. 89-90. And the Maritime Commission felt there was no chance that ratification would cause American rates to go up. Heurings, p. 41.

60. The questionnaire, and the answers thereto, may be found in Hcorings, py. S4-\$S:

61. Hearings, p. 234.

62. S. Rep. Exec. No. 4, 76th Cong., 1st. Sess. (1939). The repurt is also printed in 1939 Am. Mar. Cas. 1051. 
question rather than one of substance," the report read, "and indeed demonstrates the degree of unanimity with which the principles of the convention are accepted." 63 This particular observation must have come as a surprise to the cargo interests. The Chattahoochie decision was condemned by the report, and no objection was seen to changing its result by treaty. ${ }^{64}$ As for the insurance question, the committee found that cargo-insurance rates are governed largely by competition in a world insurance market, and that the rate is the same on cargo moving in vessels subject to the convention as on cargo moving in the vessels of nations which have failed to adopt the convention. ${ }^{0 \pi}$ The only qualifications to subcommittee support were provisions that the reservation as to presumptions be reinstated, and that the convention should not become effective in this country until one year after ratification. ${ }^{\text {i0 }}$

The report was sent to the full Foreign Relations Committee, together with a letter from Secretary of State Hull supporting the convention in the strongest terms on behalf of the Departments of State and Commerce, and the Maritime Commission. ${ }^{67}$ But the impending world crisis placed the Collisions Convention on congressional shelves once again, this time perhaps forever. The Foreign Relations Committee never took action, and on April 8, 1947. the Brussels Convention on Collision Liability was withdrawn from consideration by President Truman, in the company of a number of other treaties which, in his opinion, had become obsolete. ${ }^{68}$ No efforts have been made since then to resubmit it. An inter-departmental government committee was formed in 1953 to consider the seven unratified Brussels Conventions, but no proposals were forthcoming.

The failure of the United States to adhere to the law of collision liability followed by the rest of the world has had continuing consequences. This disparity in the collision laws, combined with varying limitation rules, has encouraged interested parties to try to resort to the courts of the nation offering

63. 1939 Am. Mar. Cas. 1055.

64. Id. at 1052. The subcommittee accepted the contention that the decision of Thr Chattahoochie frustrated the intent of the Harter Act. Because of the decision, the Senators noted that "in one important respect the policy underlying the Harter Act has never, in fact, become effective in the courts of the United States." Id. at 1055 (cmphasis added). See note 23 stpra.

65. 1939 Am. Mar. Cas. 1057.

66. Of the four original reservations to the convention, see note 11 supra, the President had recommended to the Senate the retention of the first (proportional fault shall not affect the Harter Act) and the fourth (the convention would be inapplicable in state courts). The President's letter is printed in 1939 Am. Mar. Cas. 1058.

The subcommittee report eliminated the fourth reservation entirely; amended the first by providing that it also applied to the Carriage of Goods by Sea Act; and advised that the third reservation dealing with presumptions be retained. Id. at 1056, 1057.

The subcommittee anticipated that domestic legislation would be passed in conformity with the convention, once the latter had been ratified. See text at note 56 supra. The one-year delay between ratification and operation of the convention was to ensure all interested parties a voice in such legislation. Id. at 1055

67. The letter is printed in 1939 Am. Mar. Cas. 1068.

68. 16 Dep't State Bull. 726 (1947). 
them the best bargain. ${ }^{69}$ For example, where the non-carrying ressel retains a substantial value after the collision, cargo generally prefers to bring suit in an American court and thus take advantage of the one hundred per cent recovery provided by case law. ${ }^{70}$ On the other hand, where the ship is a total loss, cargo will profit by suing in England and benefiting from the $E S$ per ton fund. ${ }^{71}$ Similarly, a shipowner whose vessel is a total loss will always attempt to localize litigation in an American court. ${ }^{72}$ However, where the value of the vessel is not seriously impaired, the shipowner's preference of a forum is influenced by the degree to which his ship was at fault, and the possibility of indirect liability to his own cargo, as well as differing limitation statutes. ${ }^{73}$

69. For example, one authority has written of the collision situation:

"This striking difference between the law of the United States and the law of the other shipping nations has sometimes led shipuwners to adofit extraordinary precautions to avoid being sued in the Unitcd Statcs, and has also given rise to some remarkable efforts by cargo to maintain suits in the Unitcd States in order to gain advantage of the American rule."

KNatte, Ocean Bills of Laping 211 (4th ed. 1953).

The parties cannot always succeed in localizing litigation in the must favorable forum. A shipowner, for reasons discussed in note 73 infra, may prefer to defend against all claims in an English court. He can petition to limit his liability in England, a yrucedure which results in a court order staying and consolidating all actions in respiect of the collision. Marsden, Colfrsions at Sea 320 (10th cd. 1953). The American limitatiun procedure has a similar effect. Robrnsox, ADMIRALT: $S S 0$ (1939). Liut a court stay wi proceedings can have no international effect. Thus, even though a shipuwner has petitionid to limit his liability in England, a claimant can still bring suit against him in the United States.

Because the jurisdiction of an American admiralty court is diseretionary when a foreign party is involved, Robisson, Adarurutr 14-20 (1939), a shipuwner may arguse that the court should decline to hear the case out of deference to a limitation fresceding commenced in another nation. But this theory was rejected in a recent Sccond Circuit opinion. The Western Farmer, 210 F.2d 754 (1954). There, a Norwegian vessel, following a collision with an American vessel carrying German-ouned cargo, limited liability in England. When the cargo brought suit in America, the Norwegian shipowner persuaded the district judge to deny jurisdiction. The Second Circuit unanimously re. versed. It is unlikely that an English court would give any greater effect to an American limitation order.

70. See text at note 19 supra.

71. Where the non-carrier is a total loss, cargo's right to $100 \%$ recovery is an empty one in America, for the owner's liability is limited to the freight pending. See test at notes 38-39 supra. An English court will limit cargo's recovery to the proportion of the non-carrier's fault, but at least there will be a fund out of which some satisiaction will be available. See text at notes 15 and 40 supra.

72. No matter how great the proportion of his fault, his liability is limited to the pending freight. See text at notes 38-39 supra.

73. A hypothetical will illustrate the situation. Assume that vessel $B$, in collision with vessel $A$, was four-fifths to blame. Cargo on $A$ was damaged by $\$ 1,060,060$. Vessed $B$ 's value after the disaster is $\$ 1,000,000$; however, the British $f \$$ per ton limitatiun system would reduce total liability to $\$ 640,000$.

Under British law, the convention would render $B$ liable fur furr-tifths of the damage to $A$ 's cargo: $\$ \$ 00,000$. This would be reduced by the limitatiun law to $\$, 40,040$. But an American forum is still more desirable; for by American law $B$ would in the 
Such factors as these compound uncertainty and render amicable settlements between the parties all the more difficult.

When in 1952 the Supreme Court finally invalidated the both-to-blame clause in Esso Belgium, ${ }^{74}$ it frustrated the efforts of carriers to escape some of the consequences of American failure to adhere to the Collisions Convention. Shipowners are now prevented from avoiding indirect liability to their cargo. ${ }^{\mathbf{7 0}}$ In Esso Belgium, cargo argued that American public policy had clecreed a one hundred per cent recovery for cargo long before the Harter Act, and that the rule of equal division of damages was similarly established. Nothing in the Harter Act had changed these policies. The sole object of the Harter Act, it was insisted, was to modify the direct liability previously existing between the carrier and its cargo. The Supreme Court agreed and, because of "the general rule of law that common carriers cannot stipulate for immunity from their own or their agents' negligence,"76 held the clause invalid as against public policy. In the view of the three dissenters, congressional desire to exempt carriers from liability for faulty navigation was in no wise inconsistent with the both-to-blame clause, which had a precisely similar effect. ${ }^{77}$

Esso Belgium, in requiring one hundred per cent recovery by cargo and the indirect liability of the carrying vessel, has prevented American law from approaching harmony with that of the rest of the martime world. The decision was greeted with dismay by ship owners and ship underwriters on both sides of the Atlantic, who foresaw, in addition to heavier liabilities, renewed confusion and maneuvering for the most favorable jurisdiction. There the situation rests today. It is evident that any progress must now be made by

end pay only half of the damage to $A$ 's cargo: $\$ 500,000$. This is so because of The Chattahoochie's rule of $50 \%$ contribution from the carrier.

However, $B$ 's preference is quite different if we assume that there was cargo on $k$, which was damaged by $\$ 500,000$. B's liability in England would still be $\$ 640,000$. But in America, in addition to the $\$ 500,000$ owing to $A$ 's cargo, under The Chattahoochic, $B$ would also be indirectly liable for half the damage to its ozen cargo: $\$ 250,000$. This would give a total liability of $\$ 750,000$; and the value of $B$ being $\$ 1,000,000$, the American limitation statute affords $B$ 's owner no comfort.

Were $B$ only one-fifth instead of four-fifths at fault, $B$ would prefer to litigate in England whether her own cargo suffered damage or not. In either case, the recovery against her would be limited to $\$ 200,000$, her share of the blame in the damage to $A$ 's cargo.

74. United States v. Atlantic Mut. Ins. Co. (The Esso Belgium), 343 U.S. 236 (1952).

75. See text at notes $23-24$ sitpra.

76. United States v. Atlantic Mut. Ins. Co. (The Esso Belgium), 343 U.S. 236, 239 (1952).

77. The majority decision has been criticized. "The Court's opinion expresses the judicial view of public policy on the point, in terms of the views prior to 1893 ; and-as the dissent of Mr. Justice Frankfurter points out-declines to recognize that the Acts of Congress of 1893 and 1936 justify the abandonment of the ancient view (100\% recovery by 'innocent cargo'), which is thus revivified for the present day." KNAUTH, OCENN Bills of Lading 210 (4th ed. 1953). See also Notes, 52 Colum. L. Rev. 1056 (1952), 51 MIICH. L. Rev. 430 (1952). 
ratification of the Collisions Convention or by domestic legislation, rather than by private contract.

\section{Maritiare Liens and Mortgages}

The problem of maritime liens and mortgages, of great commercial importance, is complicated by a high degree of international uncertainty. Rights in a vessel, whether arising out of contract claims, tort claims, or security interests, may be determined in any port at which the vessel calls. ${ }^{78}$ Chance may be the deciding factor, for with the laws of nations widely differing on the creation and enforcement of maritime liens, a lienor may have his claim substantially satisfied or entirely shut out, depending upon the jurisdiction in which the vessel is seized and sold. As Professor Robinson assessed the situation: "Nothing short of an international convention will suffice to iron out the variables which are bound to arise in respect to so ambulatory a thing as a ship."79

The International Convention of 1926 for the Unification of Law Relating to Maritime Liens and MIortgages represented twenty years of work by the Comite. ${ }^{80}$ The convention aimed at a standard list of liens and priorities among nations, to the end that interests in vessels might be predictable and the ship mortgage an effective form of security. But the Liens and Mortgages Convention has enjoyed less success than the Collisions Convention, since neither Great Britain nor the United States has adhered to it.

Wide discrepancies existed in the lien laws of various nations when the Comite began its deliberations, ${ }^{81}$ and, due to Anglo-American reluctance, they persist in large measure today. As in the case of collision liability, international conflicts of laws cause great trouble here. The problem is given crucial significance by the fact that a decree of sale in any admiralty court acting in rem receives international recognition and divests the vessel of all liens, no matter who holds them, giving the purchaser title good against the world. ${ }^{82}$ This makes the law of the forum of the utmost importance to lienors; for upon that law depend both the existence and the priority of their liens. ${ }^{83}$ As to both these factors, the English courts apply the doctrine of lex fori. A maritime lien may not be enforced at all in an English court if the local law does not provide a lien for the claim involved; and the priority of maritime liens in a foreclosure sale is strictly a matter of local procedure. si $^{\text {The Ameri- }}$ can cases embrace a different standard. When a vessel is seized and sold in

78. See text at note $\$ 2$ infra.

79. Robinson, Adamrality 435 n.226 (1939).

80. The convention is printed in 6 Benedict, Adarirality 78 (6th ed. 1940).

81. See Franck, $A \Lambda^{\prime}$ cw Law for the Scas, 42 L.Q. Rev. 25, 308 (1926).

82. For a famous American discussion which also reviews forcign authorities, see The Trenton, 4 Fed. 657 (E.D. Mich. 1880). See also The City of Athens, 83 F. Supp. 67 (D. Md. 1949); Robinson, ADMiralty 414 (1939).

83. Price, Maritiure Liens 206 (1940); Lord \& Glenn, The Forcign Ship Mortgage, 56 YALE L.J. 923, 926-27 (1947).

84. PRICE, op. cit. supra note 83 , at 207. 
an American court of admiralty, the existence of a lien is determined by the lex rei sitae: the law of the place where the facts giving rise to the alleged lien occurred. $^{85}$ In the case of liens arising out of an incident on the high seas, American courts apply "the general maritime law as understood in the United States." 86 American law on the proper priority of liens, when foreign lienors are involved, is unsettled. Our courts have not availed themselves of the English solution and treated the matter as purely procedural. Instead, some cases indicate that a lien's priority is a substantive matter and that the foreign law should be followed. ${ }^{87}$ France and Italy have adopted the convention rules regarding liens and mortgages. ${ }^{88}$ When a convention country's ship is seized and sold in either of these nations there is no conflicts problem regarding the enforcement or priority of liens. But if a vessel flying a non-convention flag is involved, the usual difficulties result. France then applies the lcx fori to both existence and priorities. ${ }^{89}$ Italy, on the other hand, holds that the law of the flag determines the presence of a maritime lien; but priorities fall under the dominion of the law of the forum. ${ }^{00}$

The Comite envisioned an international agreement which would accomplish two purposes: (1) unification of the maritime law of liens and mortgages, thus doing away with the confusion and inconvenience stemming from the conflicts of laws; and (2) improvement of the status of the ship mortgage by reducing the number of liens, so as to facilitate credit for shipowners by ensuring that the value of the security given would not be too seriously undermined. ${ }^{91}$ Ship mortgages did not provide the soundest security for investment where vessels were in international trade; there was no guarantee either that a mortgage could be enforced in a foreign port or, if the ship were sold to satisfy another lien recognized by the foreign jurisdiction, that the mortgage holder would be entitled to share in the proceeds. ${ }^{02}$ Recognizing that a uniform system of foreign ship mortgage enforcement would administer a commercial shot of adrenalin, the Comite made such a system one of its main objectives; it also realized that the job would not be complete if international accord were not reached on the number of liens taking preference over the ship mortgage.

85. Id. at 210; Robinson, Admiratty 435 (1939).

86. PRICE, op. cit. supra note 83, at 213 .

87. The Secundus, 15 F.2d 713 (E.D.N.Y. 1927) ; The Olga, 32 Fed. 329, 330 (S.D. N.Y. 1887) ; Robinson, Admiralty 435 (1939). But see The City of Athens, 83 F. Supp. 67, 78 (D. Mdd. 1949); The Oconee, 280 Fed. 927,933 (E.D. Va. 1922).

88. PRICE, op. cit. supra note 83, at 214, 216.

89. Id. at $215,216$.

90. Id. at 216 .

91. Id. at 218; Franck, The Nezv Law for the Seas, 42 L.Q. Rav. 313 (1926).

92. At the time of the Comite's formation, American law considered the ship mortgage to be a non-maritime contract, unenforceable and unrecognized in admiralty. The J.E. Rumbell, 148 U.S. 1 (1893) ; Bogart v. The John Jay, 58 U.S. (17 How.) 399 (1854); Robinson, Admiralty 194-95 (1939). English statutes granted a registered domestic mortgage recognition in admiralty, but made no provisions for a foreign ship mortgage. See Lord \& Glenn, The Foreign Ship Mortgage, 56 YaLE L.J. 923, 932 (1947). 
But in striving for agreement among many nations as to the proper number and priority of maritime liens, the principle of uniformity again came into conflict with group interests. During a series of annual meetings prior to World War I, efforts to limit the number of recognized liens were opposed by countries where established liens would have been denied recognition. ${ }^{93}$ Germany, for example, argued for the retention of its practice of granting a lien on a vessel to every creditor whose clain could be subjected to a limitation of liability proceeding. ${ }^{94}$ The American delegates were chiefly concerned with the lien in favor of any person furnishing supplies, repairs, or other necessaries to a vessel..$^{95}$ They argued that although the United States was not (at that time) a great shipowning nation, it was one to which ships frequently came. Therefore, a convention which did not recognize a lien for necessaries would find little favor here. Furthermore, American spokesmen insisted that the interests of ship mortgagees did not justify the elimination of a necessaries lien, which not only protected materialmen but also aided small shipowners in obtaining credit for immediate needs. ${ }^{06}$

A draft convention drawn up in 1913 represented the extent of the Comite's progress prior to World War I. ${ }^{97}$ It contained an exclusive enumeration of claims which would give rise to maritime liens. A lien for necessaries was included, but only for those furnished outside the home port. ${ }^{98}$ All claims secured by liens took precedence over a ship mortgage ;0 however, mortgages duly effected and registered under the laws of any contracting state would be recognized and enforced in all others. ${ }^{100}$ War prevented any positive action by the nations on the 1913 draft.

While Europe was still readjusting at the end of the war, the United States approached the problem of the ship mortgage by means of domestic legislation. The Ship Mortgage Act of $1920^{101}$ gave the mortgage the status of a maritime lien for the first time. The act created a "preferred ship mortgage" with a lien taking precedence over all others except prior liens and "preferred liens" for tort damages, wages, general average, and salvage, no matter when incurred. ${ }^{102}$ However, the Ship Mortgage Act applied only to American-held mortgages

93. The history of the Comite's efforts to achieve international uniformity in the fields of liens and mortgages is given in detail in PrICE, Maritrue Liens 218-37 (1910).

94. Id. at $218,223,226$.

95. Id. at 224 .

96. Id. at 226.

97. The 1913 draft (hereinafter cited as 1913 DRAFr) is printed in U. S. Deleastes to the 1922 Brussels Conference, Report 47-51 (1923).

98. The complete list of claims giving rise to maritime liens was as follows: (1) law costs, public taxes, and charges; (2) wages; (3) salvage and general average; (4) necessaries furnished outside the home port; (5) tort damages. 1913 Draft art. 3.

99. See British Delegates to the 1922 Brussezs Conference, Rerutit 14 (1923).

100. 1913 DRART art. 1.

101. 41 Stat. 1003 , $\$ 30(K)$ (1920), 46 U.S.C. $\S 951$ (1952).

102. Ibid. 
on American vessels; foreign mortgagees and American mortgagees of foreign vessels were still unprovided for. ${ }^{103}$

The Ship Mortgage Act also reenacted the Federal Maritime Lien Act of $1910,{ }^{104}$ which had dealt with the status of a lien for necessaries. Prior to 1910, the general maritime law granted a maritime lien only for such necessaries as were furnished in a foreign port. Materialmen furnishing supplies in the home port were left to their remedies under local law. ${ }^{105}$ Stuch confusion had been engendered by this distinction that the Act of 1910 abolished it, providing instead that a supplier of necessaries would obtain a lien enforceable in rem, whether the vessel were foreign or domestic. ${ }^{100}$ Under the Ship Mortgage Act, this necessaries lien was inferior to the mortgage lien unless incurred prior to it. ${ }^{107}$

When the delegations to the Comite reconvened in Brussels in 1922, the United States flatly declared that the 1913 draft's abolition of certain liens, especially that for necessaries furnished in a home port, rendered it unacceptable. ${ }^{108}$ In an effort to secure American support, the conference rewrote the

103. Lord \& Glenn, The Foreign Ship Mortgage, 56 YALE L.J. 923, 937 (1947).

The requirements that both the mortgaged vessel and the mortgagee be American are found in subsection D of the Act of 1920 :

"(a) : A valid mortgage which at the time it is made, includes the whole of any vessel of the United States ... shall, in addition have, in respect to such vessel and as of the date of the compliance with all the provisions of this subdivision, the preferred status given by the provisions of subsection $\mathrm{M}$, if-

...

(5) The mortgagee is a citizen of the United States ....

"(b) : Any mortgage which complies in respect to any vessel with the conditions enumerated in this subsection is hereafter in this section called a "preferred mortgage' as to such vessel."

41 STaT. $1000, \S 30$ (D) (1920); 46 U.S.C. § 922 (1952).

In addition, it is unlawful to transfer or mortgage any American-documented vessel to any person not a citizen of the United States, without the permission of the Government. 52 STAT. 964 (1938); 46 U.S.C. \& 808 (1952).

Though the Ship Mortgage Act did not make admiralty process available for the enforcement of a foreign ship mortgage, it was possible for a mortgagee who wished to foreclose in America to bring a civil action, in the nature of what was formerly a bill in equity, in a district court under what is now 28 U.S.C. $\$ 1655$ (1952). However, such proceedings were cumbersome; and, since an established ground of federal juriscliction had to be demonstrated, private mortgagees had serious difficulties. See S. Rer. No. 1213, 83d Cong., 2d Sess. 3 (1954).

104. 36 Stat. 604 (1910), now merged in 41 Stat. 1005 (1920); 46 U.S.C. $\$ \$ 971-75$ (1952).

105. The various states of the union were regarded as "foreign" to each other. The domestic state could create a lien for necessaries if it wished. The lien was then considered "maritime," and could be enforced only in a federal court. Roninson, AnMikntry 371 (1939).

106. For a discussion, see id. at 374 .

107. See text at note 102 supra and note 110 infra.

108. See British Delegates, op. cit. supra note 99, at 14.

Ratification of the 1913 draft would have reintroduced into American law the distinction between necessaries furnished in a foreign port and those furnished in the home port. 
1913 draft along the lines of existing American legislation. ${ }^{109}$ The liens ranking prior to the ship mortgage were in general the same as the preferred liens recognized by the Ship Mortgage Act.110 It was further provided that every nation was free to establish its own system of non-preferred liens which would rank above a ship mortgage if incurred prior to the registration of the mortgage, thus insuring the survival of American lien law. ${ }^{111}$ This $1922 \mathrm{draft}$, the culmination of the Comite's efforts, has been regarded as a healthy compromise between international uniformity and group interests. Ship mortgages duly recorded in onè member country were to be enforced by libels in rem in all others, and the limited number of liens taking precedence over the mortgage could not be created at the will of the owner and were easily insurable against by the mortgagee. As for the necessaries lien, although it ranked below a prior duly recorded mortgage, its efficacy was not seriously diminished, whereas placing it above the mortgage lien would have drastically undermined the latter's security value. ${ }^{112}$

The 1922 draft was accepted by several states, but most of the world awaited a lead from Great Britain and the United States. Yet, at the Genoa Conference of the Comite in 1925, these powers dealt a death blow to the convention goal of uniformity. The British representatives reported that

109. The American delegates to the 1922 conference had called the attention of the other nations to the Ship MIortgage Act; and the act was seized upon as the foundation for a compromise which, it was hoped, would secure American approval for the cunvention:

"As the result of this information it appeared to the conference that whilst it was impossible at the present stage to obtain agreement with respect to all the claims which should give rise to a lien on a vessel, there might not be the same dificulty in reaching an agreement as to the liens which should take precedence of a duly effected mortgage; and the draft convention in its present form, as ultimately agreed by all the delegates present, is an embodiment of this idea."

BRITISA Deliegates, op. cit. sitpra note 99 , at 15 .

110. The Ship Mortgage Act ranked all prior liens, and liens for turt damages, wages, general average, and salvage, above the mortgage. See text at note 105 supra. The 1922 draft ranked liens for law costs, harbor dues and other public charges, wages, salvage, general average, and tort damages above the mortgage. 1922 Dars arts. 1-3. See Britisi Delegates, op. cit. supra note 99, at 56-58.

111. 1922 DRAFT art. 3. The 1922 draft established a lien for necessaries furnished away from the home port, but provided that it would rank below the rortgage unless incurred prior to it. 1922 DRAFT arts. 2, 3. American insistence urion a lien for necessaries in the home port could be satisfied by exercising the option granted by article 3:

"Every nation is left free to establish such system of nonpreferred maritime liens as it may deem proper. Maritime liens, whether of the preferred or nunpreferred class, in existence prior to the recording of the mortgage, take precedence over the mortgage if entered in a public register, either at the purt of the vessel's registry or at a central office in the country to which the vessel belongs, within a period of three months after the lien arose"

U.S. Delegates to the 1922 Brussels Conference, Report 5 (1923).

112. Price, Maritine Lrears 230 (1940); Franck, The New Lase for the Scas, 42 L.Q. Rev. 3is, 313 (1926). 
businessmen in England demanded a more effective lien for necessaries. ${ }^{110}$ And, although the American delegation had favorably reported to the President on the 1922 draft, ${ }^{114}$ the United States informed the Comite that this country would never accept the convention. There were still too many differences between the system it contemplated and established American law. ${ }^{116}$ Furthermore, uncertainties existed as to the constitutionality of such a treaty. ${ }^{116}$ These stemmed from similar misgivings about the validity of the Ship Mortgage Act of 1920. Because the Supreme Court had in an early case held the ship mortgage to be non-maritime, ${ }^{\mathbf{1 1 7}}$ some felt the act might be construed as an invalid effort to extend admiralty jurisdiction. ${ }^{118}$ If this were so, it was thought that a treaty purporting to achieve the same results must also fall.119

Certain changes were made by the Comité in its final draft of $1926 ; 120$ but the treaty was never again urged seriously in the United States, and, though

113. "The British delegation reported that objections had been raised in England by business men who were not interested in questions of theory and had no knowledge of the work of the International Maritime Committee. The delegation emphasized the importance of the lien in favor of the necessaries men since it was by their means that the vessel was enabled to continue her voyage." PRICE, op. cit. supra note 112, at 232.

114. "The importance of securing international recognition of ship mortgages is obvious. Without such recognition the value of ship securities is greatly impaired. While the ship mortgage convention cannot be regarded as a complete and perfect document, we believe that supplemented by such national legisiation as is permissible thereunder, it should commend itself to those interested in maritime affairs." U.S. DELEGATES, op. cit. supra note 111, at 6 .

115. PRICE, op. cit. supra note 112, at 231-32.

116. Ibid.

117. Bogart v. The John Jay, 58 U.S. (17 How.) 399 (1854). See note 92 supra.

118. The Constitution granted the federal courts exclusive competence over all cases of "admiralty and maritime jurisdiction." U.S. Const. art. III, \& 2. In Bogart v. The John Jay, the Supreme Court characterized the ship mortgage as a non-maritime contract. This classification would render any subsequent effort to bring mortgages within the cognizance of admiralty courts unconstitutional, "for if the transaction were not maritime, it was not among the matters apportioned to the federal government's keeping." Rounson, AdMIRALTY 194 (1939). But The John Jay also contained language indicating that the mortgage involved was not enforceable in admiralty because the court lacked facilities to give it "remedies and protection." This might have been only because Congress had not yet acted; and its action, in the ultimate form of the Ship Mortgage Act, would not then be invalid. Robinson, Admiralty 195 (1939).

The question was resolved in favor of the act by the decision of the Supreme Court in The Thomas Barlum, 293 U.S. 21 (1934).

119. But this would not necessarily follow. "The suggestion is sometimes made that some legislative action, not directly within the constitutional power of Congress, might be brought within that power by negotiating a treaty requiring the enactment of the desired law, and then justifying the statute as implementing the treaty." 4 BenEurct, Adxiralty 278 (6th ed. 1940). See also Missouri v. Holland, 252 L.S. 416 (1920) (act of Congress regulating killing of migratory birds held valid as effectuating treaty with Great Britain, although a similar act, passed before the treaty, had been held unconstitutional).

120. The lien for necessaries furnished in a foreign port was given priority over the mortgage even if incurred subsequently, but it was to be enforceable only for six 
ratification was advocated in Great Britain, it never came about.121 A flicker of hope was raised when the Supreme Court, in The Thomas Barlum, held the Ship Mortgage Act constitutional. The theory was that if Great Britain would accept the Convention, the United States was then free to follow. ${ }^{123}$ However, this hope proved idle; and so the Comite's envisioned uniformity for maritime liens and mortgages failed of achievement.

Recent attention has focused upon the unsatisfactory status of the law regarding enforcement of foreign ship mortgages. The Bogart case had held a ship mortgage non-maritime, and thus unenforceable in admiralty courts. ${ }^{124}$ Yet only in admiralty can a foreclosure sale be effected which will give good title against the world. ${ }^{125}$ The Ship Mortgage Act of 1920 opened American admiralty courts for the enforcement of a domestic mortgage; but no statute or decision extended such benefits to the holder of a foreign ship mortgage. ${ }^{1=0}$ Similarly, in England registered domestic ship mortgages were made enforceable in admiralty by statute, and were given a relatively favorable priority position, but the situation with regard to foreign ship mortgages has remained less desirable. ${ }^{12 \pi}$ It has been argued that a 1922 English decision, The Colorado, ${ }^{123}$ had the effect of rendering foreign mortgages enforceable in English admiralty courts, thereby accomplishing by case law what had not been done by statute. ${ }^{120}$ How-

months thereafter. Other liens had a life span of one year. PRICE, of cil. supro note: 112 , at 233.

121. Id. at 237.

122. 293 U.S. 21 (1934). See Robinson, Adasiratty 195 (1939).

123. "Opposition also exists in the United States, but has perhaps been lessened by the decision in the Barlum case, where the Supreme Court held that the Ship Mortgage Act. 1920, was constitutional, thus enlarging the legislative powers of Congress with respect to the jurisdiction in Admiralty. It may, indeed, turn out that the Barlum decision will so weaken the American opposition to the Convention on constitutional gruunds that the United States might be inclined to follow if Great Britain should adopt the Conventiun. The objections must rest hereafter on business grounds only. American business men. however, appear to be well content with the present situation." PuLE, ACaminne LiEs: 236-37 (1940).

124. See notes 92 and 117 supra.

125. See S. Rep. No. 1213, 83d Cong., 2d Sess. 3 (1954); text at nute 82 supra.

126. See text at note 103 supra.

127. See note 92 supra.

128. [1923] P. 102 (C.A.).

129. The Colorado, a French vessel, was seized in England by English repairmen on a statutory lien which ranked below the lien for a domestic registered murtgage, but above a claim based on an unregistered mortgage. Belgian mortgagees under a "hy"pothèque" registered in France were held by the British court to take before the repairmin, for the French hypothèque was analogous to the English registered mortgagi, and thus entitled to the priority that English law would accord the latter. The Colorado, [1923] P. 102, 107 (C.A.).

"The Colorado case thus established that if a foreign mortgag, was enduwed by foreign law with the attributes of a maritime lien or of an English mortgage, it would be accredited the same preferential rights specifically granted by English statutes to English mortgages, even though such statutes did not in terns extend wo furcign mortgages." Lord \& Glenn, The Forrign Ship Mortgage, 56 YALE Lol. 923, 934 (1947). 
ever, it is the opinion of the Comite that the enforceability of foreign ship mortgages in that country remains uncertain and unsatisfactory. ${ }^{130}$

The American law concerning enforcement of foreign ship mortgages was recently improved. The federal government, which retained mortgages on a considerable number of vessels sold to foreign nations after World War II, 101 was inconvenienced by the lack of an available action in admiralty when it became necessary to foreclose such mortgages. ${ }^{132}$ Largely for this reason, branches of the executive looked with favor upon a proposed amendment to the Ship Mortgage Act of 1920 brought forward by the Maritime Law Association of the United States. This amendment became law in July 1954, 133 and it has the effect of giving a foreign ship mortgage, for the first time in this country, the status of a maritime lien. Under the new law, the term "preferred mortgage," previously confined to domestic ship mortgages, is expanded to include "any mortgage, hypothecation, or similar charge created as security upon any documented foreign vessel," if such security interest has been duly registered according to the laws of the foreign flag. And such a foreign mortgage shall be granted a "preferred mortgage lien" similar to that enjoyed

130. The 1951 Naples Conference of the Comite demonstrated the continuing dissatisfaction of that body with the state of the law in England. "The Conference passed a resolution repeating its recommendation that those countries that do not now afford an adequate remedy by which foreign mortgages may be foreclosed (namely England and the British Commonwealths and Possessions) should amend their laws to give such remedy." U.S. Maritime Law Ass'n, Report on Naples Conference 3502 (Doc. No. $351,1951)$.

131. "Through sales of vessels to foreign buyers under the Merchant Ship Sales Act of 1946, the United States represented by the Maritime Administration holds mortgages which secure balances of the purchase price of such war-built vessels aggregating about $\$ 125$ million." H.R. Rep. No. 1662, 83d Cong., 2d Sess. 2 (1954).

132. Maritime Administration mortgages could be enforced in the district courts under 28 U.S.C. $\$ 1655$ (1952); see note 106 supra. The requirement that federal jurisdiction be demonstrated was met by resort to 28 U.S.C. $\$ 1345$ (1952), because the suit was by the United States. But Government lawyers were dissatisfied with these cumbersome proceedings. See S. Rep. No. 1213, 83d Cong., 2d Sess. 3 (1954).

133. The amendment reads:

"Foreign ship mortgages: As used in sections 951-954 of this titlc, the tcrm "preferred mortgage" shall include, in addition to a preferred mortgage made pursuant to the provisions of this chapter, any mortgage, hypothecation, or similar charge created as security upon any documented foreign vessel (other than a tow boat, barge, scow, lighter, car float, canal boat, or tank vessel, of less than two hundred gross tons) if such mortgage, hypothecation, or similar charge has been duly and validly executed in accordance with the laws of the forcign nation under the laws of which the vessel is documented and has been duly registered in accordance with such laws in a public register either at the port of registry of the vessel or at a central office; and the term "preferred mortgage lien" shall also include the lien of such mortgage, hypothecation, or similar charge; Provided, however, That such preferred mortgage lien in the case of a foreign vessel shall also be subordinate to maritime liens for repairs, supplies, towage, use of drydock or marine railway, or other necessaries performed or supplied in the United States." 68 STAT. 323 (1954), 46 U.S.C.A. \& 951 (Supp. 1954). 
by a domestic mortgage. There is, however, one important difference: in the case of a foreign vessel, the "preferred mortgage lien" shall be subordinate to maritime liens for repairs, supplies, towage, or other necessaries performed or supplied in the United States, as well as to liens having priority over domestic ship mortgages.

The inclusion of this last provision was occasioned by factors which recall the unhappy fate of the 1926 convention in this country. Originally, the Naritime Law Association's proposed amendment contained no such clause. However, in 1951, to meet the objections of ship repairmen and possibly other domestic lienors, it was included, but with no requirement that necessaries be furnished in the United States. ${ }^{134}$ When representatives of the Association were in Washington soliciting support for the amendment, the Maritime Administration insisted that the proviso preferring repairs and necessaries to the foreign mortgage lien be restricted to those supplied in this country. ${ }^{135}$ The members of the Association, accustomed to long contact with other nations through the Comite, and perhaps more sensitive to the foreign point of view, objected that such a restricted proviso would be unfavorably regarded on the other side of the Atlantic. Such a reaction, they argued, would be particularly unfortunate in the light of the Association's hopes that Great Britain would respond to the new law by passing a similar statute, granting non-British mortgages recognition in British admiralty courts. ${ }^{138}$ But the refusal of the Secretary of Commerce to recommend the bill unless only domestic repairmen were favored proved decisive. ${ }^{137}$

There is some uncertainty as to the intended scope of the new .American amendment. The language of the statute provides for the inclusion in the term "preferred mortgage" of "any mortgage . . . created as a security upon any foreign vessel."138 This would appear to extend admiralty process in our courts to any mortgagee of a foreign vessel, whether or not the mortgagee is an American citizen. Yet it has been argued that American citizenship on the

134. The clause read: "Prozided how'ever, that such 'preferred mortgage lien' in the case of a foreign vessel shall also be subordinate to maritime liens for repairs, supplies, towage, use of drydock or marine railway, or other necessaries." U.S. MLANITISE Law: Ass'n, Proceedings of Annual Meeting 3477 (Doc No. 346, 1951).

135. See U.S. Mlartimse Law Ass'n, Proceenings of Ansual Mrettisg 3562 (Doc. No. 359, 1952). The Maritime Administration proposed adding the words "periormed or supplied in the United States" to the provision. The reason given for restrieting the favored necessaries lien to those furnished in this country was that otherwise American mortgagees of foreign vessels might lose their advantage with respect to foreign liens in eases where the law of the flag would have subordinated the liens to the mortgage.

136. Ibid.

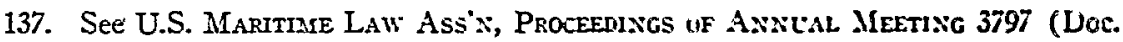
No. 382, 1954). The Secretary of Commerce felt that "there apucars to be no reason to include within the operation of the proviso liens arising from repairs and supplies furnished outside the United States, and thereby give a foreign rejairman a priority which even under the laws of his own country might not be accorded him." S. Rer. No. 1213, 83d Cong., 2d Sess. 2 (1954).

138. See note 133 supra. 
part of the mortgagee is a prerequisite to the benefits of the amendment. ${ }^{100}$ Proponents of this thesis point out that the stated primary intent of Congress in passing the new law was to afford American mortgagees, notably the Government, with adequate relief. ${ }^{140}$ Moreover, confining the effect of the amendment to American-held mortgages would be more consistent with the original statute, the Ship Mortgage Act, which was limited by its terms to domestic mortgagees and domestic vessels. ${ }^{141}$ Against this background, it is said, if Congress had really meant to benefit foreign mortgagees by this addition, it would have more clearly expressed its intention. Therefore, until Congress does so, a broader interpretation of the statute should be rejected, especially since it might flood American courts with foreign litigation. ${ }^{142}$

But other considerations militate against narrow construction of the 1954 amendment. The statutory language appears unambiguous, and the legislative history contains no indication of a desire to exclude foreign mortgagees. While it is true that Congress' primary intent was to benefit American investors, ${ }^{140}$ this should not of itself limit the effect of the amendment. American limitation of liability statutes were passed with the avowed ptrpose of stimulating domestic shipowners $;^{144}$ yet foreigners have long been held entitled to their protection in American courts. ${ }^{145}$ In addition, the amendment specifically restricts the sections of the Ship Mortgage Act which apply to the foreign ship mortgage to those referring to mortgage enforcement. ${ }^{146}$ This would seem to render the citizenship requirements for the domestic mortgage, contained in earlier sections, irrelevant in the case of a foreign vessel and its mortgagee. ${ }^{\mathbf{1 4 7}}$

139. This argument has been made by the libellant in a recent case now awaiting decision by the United States District Court for the Balboa Division of the Canal Zonc. The Aruba, Admiralty No. 3996. The litigation involves the proceeds of a foreclosure sale of a foreign vessel, with a foreign mortgagee as intervenor.

140. See note 132 supra and accompanying text.

141. See text at note 103 supra.

142. The danger of foreign litigants besieging American courts would be kecn in any port where international traffic is heavy. The Canal Zone presents a striking example.

143. "But the Ship Mortgage Act at present offers no remedy to American holders of mortgages on foreign-flag vessels. This bill is designed to correct the situation by extending the term "preferred mortgage" as used in the Ship Mortgage Act to mortgages on foreign vessels when duly executed and registered in accordance with the laws of the foreign nation under which the vessel is documented." H.R. REP. No. 1662, 83d Cong., 2d Sess. 2 (1954). See text at note 132 supra.

144. See Hartford Acc. Co. v. Southern Pac. Co., 273 U.S. 207, 214 (1927) ; Roninson, AdMIRALTY 878 (1939).

145. See The Titanic, 233 U.S. 718, 731 (1914); Robinson, AduriratTy 902 (1939).

146. See the amendment quoted note 133 supra. Sections $952-54$ deal with the receiver in foreclosure, the priorities of the liens, and the ability of a mortgagee to sue in admiralty in the event of a default. 41 STAr. $1003 \$ \S \mathrm{K}, \mathrm{L}, \mathrm{M}, \mathrm{N}(1920) ; 46$ U.S.C. $\$ \S 951-54$ (1952).

147. "Our amendment to the 1920 act specifies the sections of the act which arc made applicable to a foreign ship mortgage and thus avoids any involvment with the recuirement of an affidavit of citizenship." Letter from John C. Prizer, Chairman of the Committee on Enforcement of Foreign Ship Mortgages of the Maritime Law Association, to the Yale Laze Journal March 10, 1955, on file in Yale Law Library. 
The 1954 amendment should be held applicable to foreign mortgagees as well as domestic ones. The amendment was fostered by the Maritime Law Association, the American branch of the Comite; ${ }^{148}$ and in the absence of a clear congressional mandate to the contrary, it should be construed so as to further the principle of international uniformity towards which the Comite has directed its efforts. The status of the foreign ship mortgage would remain unresolved if the courts should hold that only domestic mortgagees were protected by the new statute. In contrast, if the 1954 amendment is interpreted to mean what it says, it may be hoped and expected that Great Britain will soon enact legislation granting similar relief to holders of foreign ship mortgages. ${ }^{149}$

It would appear, then, that by a combination of Anglo-American legislation and European adherence to the 1926 Convention, the status of the foreign ship mortgage may be resolved in relatively satisfactory fashion. But international uniformity on the related problem of maritime liens is a dream now long faded.

\section{Conclusions And Suggestions}

The history of these two Brussels Conventions reveals the essential conflict between the fundamental principle of international uniformity and various private interests. It is evident that uniformity cannot be achieved in any significant part of the maritime law without concessions from certain quarters. What must be determined in each instance is whether or not international harmony is of sufficient commercial and legal importance to justify the concessions.

\section{Collision Liablity}

American adherence to the Collisions Convention would be a desirable development. Every other important maritime nation subscribes to the modern equitable principle of proportional fault; in clinging to a rigid rule of equal damages even where unequal degrees of blame exist, this country stubbornly turns its back on progress. Furthermore, the unique position of the United States regarding collision liability, resulting from failure to ratify the treaty and invalidation of the both-to-blame clause, has awkward consequences in litigation. With the two judicial systems offering advantages to different

148. See text at note 132 sitpra.

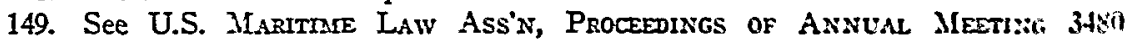
(Doc No. 346, 1951).

The Comité itself had considered drafting a convention which would apply only to the enforcement of foreign ship mortgages, isolating the troublesome question of lien priorities. In 1951, the Maritime Law Association of the United States passed a resulution in favor of proposing such a convention at the next meeting of the Comits. Ibid. Rut, since this, country proceeded by means of domestic legislation, the international organization contented itself with expressions of impatience and encouragement, directed at those nations which had not adhered to the 1926 convention. See U.S. MAaritme Law Ass':;, Repots 0:: Naples Conference 3505 (Doc. No. 351, 1951). 
parties, forum-shopping, multiplicity of suits, and obstacles to amicable settlements inevitably follow.

No national policy militates against ratification of the Collisions Convention. If anything, congressional legislation in the field is consistent with the restults which would be attained by the convention, at least insofar as the immunity of a carrier from liability to its cargo is concerned. ${ }^{150}$ This was expressly recognized by the Senate subcommittee which considered the convention. ${ }^{151}$

But the degree of opposition to the convention on the part of American cargo interests is a reflection of their considerable economic stake in preserving the status quo. The rights of cargo are substantial and established, and are entitled to careful consideration before being altered.

A possible compromise solution is presented in a proposal made by the British delegation to the Brighton conference of the Comite Maritime International in September 1954. It involves a suggested increase in the funds which English law provides for limitation of liability proceedings. At present, the funds made available in Great Britain are $£ 8$ per ton for property clamage and $£ 15$ per ton if loss of life or personal injury is involved. ${ }^{162}$ These limits were fixed by an 1862 statute based upon the then average value per ton of the British mercantile marine. ${ }^{153}$ The British Maritime Law Association believes that, in view of subsequent world inflation, the principle of limitation of shipowners' liability may fall into community disfavor if the limits are not increased to provide a more realistic recovery. ${ }^{154}$ To this end, it was proposed at Brighton that for property damage the fund would consist of $£ 24$ per ton, and for death or injury claims $£ 50$ per ton. If this latter fund should not satisfy all claims upon it, death and injury claimants would share pari passu with the property claimants in the fund established by the $£ 24$ per ton. The British Association suggested that this scheme be embodied in a new international convention, which would replace the relatively unsuccessful Brussels Limitation Convention of $1924 .{ }^{155}$

150. No congressional policy is on record concerning the other major alteration of American law that ratification of the convention would bring about: replacement of the equal division of damages rule by that of proportional liability. Sce note 22 supra.

151. See note 64 supra.

152. See text at note 40 supra.

153. The Merchant Shipping Act, 1862, 57 \& 58 Vict., c. 60.

154. See proposals of British Maritime Law Ass'n on Limitation of Shipowners' Liam bility, July 22, 1954, at 2, 3 (on file in Yale Law Library). The British Association stated:

"British shipowners regard this matter as one of great importance and indeed urgency. Having regard to the recent heavy increase in the sums awarded by the Tribunals in all countries to loss of life and personal injury claimants and to the steady increase in commodity values, they consider that it would be unwise as Ibid. well as inequitable to attempt to hold to the existing limits under English law."

155. Preferring international treatment of the problem to domestic legislation, the British Association distributed drafts of a proposed convention built around the new limitations to all members of the Comité on December 10,1954. (Draft on file in Yalc Law Library.) 
Acquiescence in revision of American law on limitation of liability along the lines of the recent British proposal would represent a considerable concession on the part of shipowners. Whereas now if the vessel is totally lost property damage goes unrecompensed and death and injury claims are limited to a sixty dollars per ton fund, ${ }^{156}$ this new proposal would tend to increase materially the shipowner's liability to both types of claimants.

The American delegates promised to report the proposal of the British group to the Maritime Law Association of the United States upon their return and discussions may ensue in the near future. In view of the close connection between the limitation system and collision liability, reformation of the former might lead to changes in the latter. If the shipping industry in this country can be persuaded to favor the British proposal regarding limitation of liability, then cargo interests, having received a considerable concession, may reasonably be expected to withdraw their objections to the Collisions Convention. Indeed, just such a compromise was tentatively suggested by the spokesman for cargo at the Senate hearings in 1938. ${ }^{157}$

American shipowning interests should carefully weigh the merits of the British proposal on limitations. If approved, it could be made the lever by which the United States is moved into line with the rest of the world on the important question of collision liability.

\section{Maritime Liens and Mortgages}

The indifferent success of the Liens and Mortgages Convention indicates that the principle of international uniformity cannot apply to some facets of the maritime law. American insistence on a lien for necessaries was only typical of the various pressures asserted by groups in other nations. Maritime liens appear to be too influenced by national characteristics to lend themselve. to regulation by an international convention. Their creation and priorities will in all likelihood remain a matter of national law.

Enforcement of a foreign ship mortgage, however, presents no great difficulty. Solely the interests of the immediate parties are at stake in a simple foreclosure suit. The troublesome priority question, which has obstructed international uniformity, arises only when the mortgage lien is competing with other liens. It is unfortunate that mortgage enforcement provisions were included in the doomed Liens Convention; in attempting to accomplish too much, the Comité accomplished less than was possible. The recent statutory amendment regarding foreign mortgages in the United States suggests that those nations which balked at the lien provisions of the convention might have been willing to handle mortgages separately. It is hoped that progress in this particular field will be continued through legislation in Great Britain and in ather nations not now adequately providing for the enforcement of foreign ship mortgages. This would greatly enhance the security value of the mortgage, and thus provide another example of the benefits to be derived from uniformity in the maritime law.

156. See text at notes 38-39 supra.

15\%. See text at notes $43-44$ supra. 